\title{
Change of the apparent digestibility of nutrients and phosphorus as a function of phosphorus source and phytase supplementation in pigs
}

\author{
J. Gundel ${ }^{1,3}$, Á. Regius Mőcsényi ${ }^{1}$, A. Hermán ${ }^{1}$, H. Fébel${ }^{1}$, \\ Sz. Huszár ${ }^{1}$, M. Szelényi ${ }^{1}$ and A. Szabó ${ }^{2}$
}

\author{
${ }^{1}$ Research Institute for Animal Breeding and Nutrition \\ 2053 Herceghalom, Hungary \\ ${ }^{2}$ University of Kaposvár, Faculty of Animal Science, \\ Department of Animal Physiology \\ P.O. Box 16, 7401 Kaposvár, Hungary
}

(Received 21 May 2003; revised version 8 October 2003; accepted 14 January 2004)

\begin{abstract}
The objective of the experiment was to examine the effect of phytase addition on absorption and apparent digestibility of $\mathrm{P}$ when a maize-soyabean meal-based diet was supplemented by different levels of inorganic phosphate. An isotope $\left({ }^{32} \mathrm{P}\right)$ metabolic experiment was carried out on crossbred barrows (initial BW of $15-18 \mathrm{~kg}$ ). The dietary treatments were arranged in a $2 \times 2$ factorial design with two levels of total P (A:0.67 and L:0.59\%) having different levels of P bioavailability (A:0.36 and L: $0.28 \%$ ), and two levels of microbial phytase ( 0 and $500 \mathrm{FTU} / \mathrm{kg}$ of diet). In phase 1 the pigs in groups $1 / \mathrm{a}$ and $1 / \mathrm{b}$ were fed diets with two levels of $\mathrm{P}(\mathrm{A}$ and $\mathrm{L}$ ) without phytase. In phase 2 , these pigs were fed diets of A and L with enzyme supplementation (groups 2/a and 2/b). The apparent digestibility of nutrients was unaffected by phytase. Pigs fed diet L had decreased organic matter- and ether extract digestibility. In group $1 / \mathrm{a}$ the piglets digested $52.3 \%$ of the total $\mathrm{P}$ and a similar value was found in group $1 / \mathrm{b}$. As the result of phytase supplementation, the digestibility of the total $\mathrm{P}$ increased by $7 \%$ in group $2 / \mathrm{a}$ and $23 \%$ in group $2 / \mathrm{b}$. The digestibility of $\mathrm{P}$ originating from inorganic $\mathrm{P}$ supplementation (monocalcium phosphate) decreased by 11 and $4 \%$ in groups $2 / \mathrm{a}$ and $2 / \mathrm{b}$, respectively. The apparent digestibility of phytate $\mathrm{P}$ was not affected in the animals fed the diet without enzyme supplementation $(1 / \mathrm{a}$ and $1 / \mathrm{b})$. However, phytase enhanced the apparent digestibility of phytate $\mathrm{P}$ from 31.6 to $43.9 \%$ and from 35.8 to $54.5 \%$ in pigs fed diet $2 / \mathrm{a}$ and $2 / \mathrm{b}$, respectively. These results show that faecal excretion of inorganic $\mathrm{P}$ increases and absorption of phytate-P improves by the action of phytase. In summary, the amount of inorganic $\mathrm{P}$ supplementation can be decreased and it is environmentally advantageous to replace inorganic $\mathrm{P}$ with microbial phytase.
\end{abstract}

KEY WORDS: phytase, phosphorus, digestibility, pigs

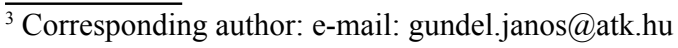




\section{INTRODUCTION}

Optimising the supply of nutrients, including phosphorus (P), has been engrossing the attention of nutritionists for a long time. Earlier the primary objective was to avoid nutritional deficiencies and, since the bioavailability of different $P$ sources was little known, in some cases supplementation substantially exceeded the requirement. According to our current state of knowledge, a high allowance in supplementation is unnecessary; such over-supplementation is even harmful as it increases the environmental load. In this light, experiments were conducted with piglets receiving different levels of $\mathrm{P}$ to monitor the availability of native and inorganic $\mathrm{P}$ for absorption when a feed of high phytate phosphorus was fed with and without phytase supplementation.

The excretion of $\mathrm{P}$ can be divided into three parts (Rodehutscord, 2001). Theoretically $\mathrm{P}$ is excreted even in the case of $\mathrm{P}$-free nutrition, primarily in the faeces and possibly also in the urine, as a consequence of the endogenous secretion of phosphates, which is postulated to be a body weight-related function in monogastric animals (in ruminants it depends on feed intake and energy supply). In the light of recent experimental findings, this loss is the so-called unavoidable proportion, which is independent of supply, and is estimated at $7 \mathrm{mg} / \mathrm{kg} \mathrm{BW}$ per day (Jongbloed and Everts, 1992; Rodehutscord et al., 1998), less than 10\% of which is excreted in the urine. The second component of $\mathrm{P}$ excretion is regulated by a balance depending on the level of supply. Supplementation of $\mathrm{P}$ in excess of requirements will result in an increased rate of excretion both in the faeces and in the urine (Fernández, 1995), indicating that this part of excretion depends exclusively on the supply. Thirdly, the act of forming dietary $\mathrm{P}$ compounds also affects the rate of excretion (e.g., phytate phosphorus). According to Günther and Al-Masri (1988), the binding form of inorganic $\mathrm{P}$, and primarily of native $\mathrm{P}$, exerts a greater influence on the mechanism of endogenous $\mathrm{P}$ excretion than does the total $\mathrm{P}$ content of the ration.

The objective of this experiment was to study the digestibility and excretion of phytate $\mathrm{P}$ and inorganic $\mathrm{P}$ derived from monocalcium phosphate (MCP, $\left.\mathrm{Ca}\left(\mathrm{H}_{2} \mathrm{PO}_{4}\right)_{2} \cdot \mathrm{H}_{2} \mathrm{O}\right)$ used as a mineral supplement in piglets receiving different levels of $\mathrm{P}$ in a diet with a high phytate phosphorus content with and without phytase supplementation. A radioisotope labelling technique was used for differentiation of the two different phosphate sources. The objective of the nutrition-physiological experiment, based on a radiolabelling technique, was to obtain further data on the excretion of $\mathrm{P}$ when using phytase supplementation.

\section{MATERIAL AND METHODS}

Metabolic experiments were conducted with twelve Hungarian Large White $\times$ Dutch Landrace breed piglets of $15-18 \mathrm{~kg}$ starting liveweight, in a $2 \times 2$ design. The 
ration was $600 \mathrm{~g} /$ day, divided in two equal parts. The animals had free access to drinking water. After an adaptation period of $9 \mathrm{~d}$ the pigs were given a daily ${ }^{32} \mathrm{P}$ isotope dose of $6 \mathrm{MBq}\left(\mathrm{H}_{3}{ }^{32} \mathrm{PO}_{4}\right.$ carrier-free; Isotope Institute Ltd., Budapest) for 7 days. Faecal sample collection started from the third day of radioactivity administration. In the five-day radioactive balance and metabolic trial, the faeces collected at $24 \mathrm{~h}$ intervals was weighed, processed and homogenized for determining the specific activity of ${ }^{32} \mathrm{P}$, from which the relevant $\mathrm{P}$ content was calculated. ${ }^{32} \mathrm{P}$ activity was determined by an ND 310 type scintillation detector fitted with a NaI (TI) $40 \times 40 \mathrm{~mm}$ crystal and connected with an NK 350 type counter.

Faecal samples were dried in an oven at $60^{\circ} \mathrm{C}$. The dried faecal samples, along with a sample of each diet, were ground to pass through a 1-mm sieve and analysed for DM and other nutrients according to AOAC (1990) procedures. Faecal and feed samples were ashed in a muffle furnace at $550^{\circ} \mathrm{C}$ for $12 \mathrm{~h}$. Approximately $30 \mathrm{ml}$ of $18 \% \mathrm{HCl}$ solution were added to wet the ashed samples. Samples were heated on a hot plate until completely dried. Ten millilitres of $1 \mathrm{M} \mathrm{HNO}_{3}$ were added to dissolve the precipitate and then transferred to a volumetric flask. The flask was filled to $500 \mathrm{ml}$ with distilled water and the content filtered into an Erlenmeyer flask. The filtrate was then used for analysis of P. Total P concentrations were determined using the vanadomolybdate procedure (AOAC, 1990) by spectrophotometric analysis.

The effects of phosphorus level and phytase enzyme were investigated by means of two-way analysis of variance (GLM procedure), taking both above conditions as fixed factors into account. Between-treatment differences were determined using the LSD (least significant difference) post hoc test. SPSS 10. for Windows (1999) was used for the statistical analysis.

\section{RESULTS AND DISCUSSION}

The amount of phosphorus absorbed from dietary components is strongly limited because of the high proportion of phytate P. According to the literature (Kirchgessner, 1994; Schulz, 1997), the digestibility of phosphate in maize, extracted soyabean, and monocalcium phosphate is 15,35 and $90 \%$, respectively. The total $\mathrm{P}$ requirement of piglets of the age group used in this study according to NRC (1998) is $6 \mathrm{~g} / \mathrm{kg}$ and the available P requirement is $3.2 \mathrm{~g} / \mathrm{kg}$ of diet. According to the data in Table 2, total and available $P$ supply met the requirements in groups $1 / \mathrm{a}$ and $2 / \mathrm{a}$, while in groups $1 / \mathrm{b}$ and $2 / \mathrm{b}$, the required level was suboptimal. The Ca:P ratio was approximately 1.1:1 and 1.05:1 for the two treatments, respectively.

The dietary P level had no significant effect on apparent digestibility of total $\mathrm{P}$ in pigs fed diets $1 / \mathrm{a}$ and $1 / \mathrm{b}$ (Table 3 ). Phytase supplementation increased the apparent digestibility of phosphorus by about $7 \%$ in animals of group $2 / a$ and 
TABLE 3

Apparent digestibility of the total $\mathrm{P}$

\begin{tabular}{|c|c|c|c|c|c|c|c|c|}
\hline \multirow[b]{2}{*}{ Item } & \multicolumn{4}{|c|}{ Groups } & \multirow[b]{2}{*}{ SEM } & \multicolumn{3}{|c|}{$P$-value } \\
\hline & $1 / \mathrm{a}$ & $1 / \mathrm{b}$ & $2 / a$ & $2 / b$ & & $\mathrm{P}$ & Phy $^{1}$ & $\begin{array}{l}\mathrm{P} \times \\
\text { Phy }\end{array}$ \\
\hline Intake, mg & 4008 & 3558 & 4008 & 3558 & 0 & - & - & - \\
\hline Faecal excretion, mg & $1907^{\mathrm{c}}$ & $1683^{\mathrm{b}}$ & $1762^{\mathrm{b}}$ & $1260^{\mathrm{a}}$ & 75 & 0.001 & 0.001 & 0.008 \\
\hline Absorbed, mg & $2101^{\mathrm{b}}$ & $1875^{\mathrm{a}}$ & $2246^{\mathrm{c}}$ & $2298^{c}$ & 52 & 0.062 & 0.001 & 0.008 \\
\hline Apparent digestibilty, \% & $52.4^{\mathrm{a}}$ & $52.7^{\mathrm{ab}}$ & $56.0^{\mathrm{b}}$ & $64.6^{c}$ & 1.6 & 0.003 & 0.001 & 0.004 \\
\hline
\end{tabular}

${ }^{1}$ Phy $=$ microbial phytase

${ }^{\text {a,b,c }}$ within a row, means lacking a common superscript letter differ $(P<0.05)$

TABLE 4

Apparent digestibility of nutrients, $\%$

\begin{tabular}{|c|c|c|c|c|c|c|c|c|}
\hline \multirow{2}{*}{ Item } & \multicolumn{4}{|c|}{ Groups } & \multirow{2}{*}{ SEM } & \multicolumn{3}{|c|}{$P$-value } \\
\hline & $1 / \mathrm{a}$ & $1 / \mathrm{b}$ & $2 / \mathrm{a}$ & $2 / b$ & & $\mathrm{P}$ & Phy $^{1}$ & $\mathrm{P} \times$ Phy \\
\hline Dry matter & 88.3 & 87.5 & 88.7 & 88.9 & 0.2 & 0.195 & 0.059 & 0.195 \\
\hline Organic matter & $89.3^{\mathrm{b}}$ & $88.0^{\mathrm{a}}$ & $89.7^{b}$ & $89.0^{\mathrm{ab}}$ & 0.2 & 0.028 & 0.083 & 0.414 \\
\hline Crude protein & $85.6^{\mathrm{ab}}$ & $83.0^{\mathrm{a}}$ & $86.3^{b}$ & $84.4^{\mathrm{ab}}$ & 0.5 & 0.029 & 0.285 & 0.786 \\
\hline Crude fibre & 63.5 & 59.7 & 67.7 & 65.6 & 1.6 & 0.310 & 0.140 & 0.709 \\
\hline Ether extract & $43.6^{\mathrm{bc}}$ & $38.0^{\mathrm{a}}$ & $48.2^{\mathrm{c}}$ & $41.6^{\mathrm{ab}}$ & 1.4 & 0.004 & 0.033 & 0.883 \\
\hline
\end{tabular}

${ }^{1}$ Phy $=$ microbial phytase

a,b,c within a row, means lacking a common superscript letter differ $(P<0.05)$

by nearly $23 \%$ in animals of group $2 / \mathrm{b}$. The $\mathrm{P}$ intake and faecal excretion data show a tendency similar to the results reported by Hoppe (1992) and Gundel et al. (1998).

Phytase supplementation may significantly improve the digestibility of nutrients other than phosphorus. In experiments conducted on pigs, Kemme et al. (1999) observed a $2.5 \%$ increase in the apparent ileal digestibility of crude protein. Other authors (Khan and Cole, 1993; Gundel et al., 1998) reported a 12-14\% increase in faecal digestibility of crude protein. In contrast, in experiments with phytase supplementation, Pallauf et al. (1994) and Traylor et al. (2001) did not observe any improvement in the digestibility of crude protein. Our findings seem to support the observations of the latter researchers. The data presented in Table 4 indicate that the apparent digestibility of crude protein scarcely changed as a result of phytase supplementation. Similarly, no significant changes were found in the apparent digestibility of other nutrients following phytase supplementation. Hartman (1979) stated several decades ago that 2-3\% of soyabean protein forms a very stable complex with phytate. The binding form of this complex determines the extent to which the digestibility of protein can be increased by enzyme supplementation. The type of the phytate-protein complex cannot be predicted, and 
presumably this is responsible for the contradictory results occasionally obtained on protein digestibility when concentrates high in phytate are fed (Gifford and Clydesdale, 1990).

The results obtained pertaining to absorption of inorganic $\mathrm{P}$ using a radioisotope $\left({ }^{32} \mathrm{P}\right)$ method are summarised in Table 5. According to the data found in the literature, the apparent digestibility of $\mathrm{P}$ from MCP is $90 \%$, which appears to be

TABLE 5

Intake, faecal excretion and apparent digestibility of inorganic $\mathrm{P}$

\begin{tabular}{lcccccccc}
\hline \multirow{2}{*}{ Item } & \multicolumn{4}{c}{ Groups } & & \multicolumn{3}{c}{$P$-value } \\
\cline { 2 - 5 } \cline { 7 - 9 } & $1 / \mathrm{a}$ & $1 / \mathrm{b}$ & $2 / \mathrm{a}$ & $2 / \mathrm{b}$ & & $\mathrm{P}$ & Phy $^{1}$ & $\mathrm{P} \times$ Phy \\
\hline Intake, mg & 1642 & 1094 & 1642 & 1094 & 0 & - & - & - \\
Faecal excretion, mg & $290^{\mathrm{b}}$ & $101^{\mathrm{a}}$ & $436^{\mathrm{c}}$ & $140^{\mathrm{a}}$ & 44 & 0.001 & 0.053 & 0.225 \\
Absorbed, mg & $1352^{\mathrm{c}}$ & $993^{\mathrm{a}}$ & $1206^{\mathrm{b}}$ & $954^{\mathrm{a}}$ & 52 & 0.001 & 0.053 & 0.225 \\
Apparent digestibilty, $\%$ & $82.3^{\mathrm{b}}$ & $90.8^{\mathrm{c}}$ & $73.4^{\mathrm{a}}$ & $87.2^{\mathrm{bc}}$ & 2.2 & 0.002 & 0.037 & 0.317 \\
\hline
\end{tabular}

${ }^{1}$ Phy $=$ microbial phytase

a,b,c within a row, means lacking a common superscript letter differ $(P<0.05)$

somewhat overestimated in the light of earlier literature data (Gundel et al., 1998) if the $\mathrm{P}$ supply met requirements. On the other hand, if the supply failed to meet the requirement, and if rations with a high phytate $\mathrm{P}$ content were fed, the digestibility of $\mathrm{P}$ from MCP (treatment $1 / \mathrm{b}$ ) increased from 82.3 to $90.8 \%$, indicating that phosphorus deficiency resulted in maximum digestibility of inorganic P. In the case of phytase supplementation, the apparent digestibility of $\mathrm{P}$ derived from MCP decreased both at a $\mathrm{P}$ level satisfying the requirement and at that failing to meet it (by 11 and $4 \%$, respectively). The higher amount of absorbed inorganic $\mathrm{P}$ at a phosphorous supply below the required level supports the existence of a correlation between supply and digestibility (Fernández, 1995), while the decrease occurring in the digestibility of inorganic $\mathrm{P}$ as a result of phytase supplementation indicates that, of the total $\mathrm{P}$ contained in the ration, the amount of absorbed phytate $\mathrm{P}$ increases. The above statement will become even more important if we consider that the use of $\mathrm{P}$ supplements of animal origin is prohibited, which results in a higher demand on inorganic $P$ sources and on phytate phosphorus of increased digestibility.

In the groups without enzyme supplementation (groups $1 / \mathrm{a}$ and $1 / \mathrm{b}$ ), dietary $\mathrm{P}$ intake and the amount of $\mathrm{P}$ excreted in the faeces were similar, therefore the apparent digestibility of phytate P did not differ significantly between these groups (Table 6). As a result of phytase supplementation, the digestibility of phytate $\mathrm{P}$ increased significantly from 31.6 to $43.9 \%$ in group $2 /$ a receiving $P$ according to requirements and from 35.8 to $54.5 \%$ in group $2 / \mathrm{b}$, which received a $\mathrm{P}$ supply below the requirement. The results of earlier studies (Pallauf et al., 1994; Düngelhoef and Rodehutscord, 1995) also indicate that phytase decreases the faecal excretion of phytate P. Using phytase supplementation of $400 \mathrm{FTU} / \mathrm{kg}$, Hoppe (1992), achieved a $1 \mathrm{~g}$ saving of 
TABLE 6

Apparent digestibility of phytate $\mathrm{P}$ in a maize-soyabean meal based diets

\begin{tabular}{|c|c|c|c|c|c|c|c|c|}
\hline \multirow{2}{*}{ Item } & \multicolumn{4}{|c|}{ Groups } & \multirow{2}{*}{ SEM } & \multicolumn{3}{|c|}{$P$-value } \\
\hline & $1 / \mathrm{a}$ & $1 / \mathrm{b}$ & $2 / \mathrm{a}$ & $2 / b$ & & $\mathrm{P}$ & Phy $^{1}$ & $\mathrm{P} \times$ Phy \\
\hline Intake, mg & 2366 & 2464 & 2366 & 2464 & 0 & - & - & - \\
\hline Faecal excretion, mg & $1617^{b}$ & $1582^{b}$ & $1326^{\mathrm{a}}$ & $1120^{\mathrm{a}}$ & 68 & 0.134 & 0.001 & 0.268 \\
\hline Absorbed, mg & $749^{a}$ & $882^{\mathrm{ab}}$ & $1040^{\mathrm{b}}$ & $1344^{\mathrm{c}}$ & 74 & 0.016 & 0.053 & 0.268 \\
\hline Apparent digestibilty, $\%$ & $31.6^{\mathrm{a}}$ & $35.8^{\mathrm{ab}}$ & $43.9^{\mathrm{b}}$ & $54.5^{\mathrm{c}}$ & 2.9 & 0.042 & 0.001 & 0.318 \\
\hline
\end{tabular}

${ }^{1}$ Phy $=$ microbial phytase

a,b,c within a row, means lacking a common superscript letter differ $(P<0.05)$

MCP. Replacement values were introduced to calculate how much inorganic $\mathrm{P}$ can be saved by $500 \mathrm{U}$ of phytase. A more sophisticated evaluation is based on digestible P because inorganic P sources differ in digestibility. According to Düngelhoef and Rodehutscord (1995), a replacement value of $0.16 \mathrm{~g}$ digestible $\mathrm{P}$ per $100 \mathrm{U}$ was calculated, which is valid up to a supplementation of $500 \mathrm{U} / \mathrm{kg}$.

The data in Table 6 indicate that slightly more than $30 \%$ of the phytate $\mathrm{P}$ intake was absorbed in groups $1 / \mathrm{a}$ and $1 / \mathrm{b}$. By using phytase supplementation, the amount of absorbed phytate $\mathrm{P}$ increased by 39 and 52\%, respectively. This latter figure seems to support the earlier experimental findings of Düngelhoef and Rodehutscord (1995), who suggested that the phytate-hydrolysing activity of phytase was higher at a lower level of inorganic P supplementation.

\section{CONCLUSIONS}

The same apparent digestibility data obtained in animals fed diets with adequate and lower levels of total $\mathrm{P}$ and available $\mathrm{P}$ indicate that the current requirement values of $\mathrm{P}$ for pigs should be revised. The current recommendations for requirements of total $\mathrm{P}$ and even for available $\mathrm{P}$ can be reduced in pigs.

The results of radioisotope studies of ${ }^{32} \mathrm{P}$ metabolism confirm the hypothesis that phytase supplementation increases faecal excretion of inorganic $\mathrm{P}$ within total $\mathrm{P}$ and enhances the absorption of phytate $\mathrm{P}$. By increasing the digestibility of phytate $\mathrm{P}$, the amount of inorganic phosphate used for supplementing diets can be decreased.

The significantly higher apparent digestibility of the total amount of $\mathrm{P}$ obtained in pigs fed phytase-supplemented diets but with less $P$ than required indicate that a lower level of inorganic $\mathrm{P}$ supplementation should be used in the rations fed to piglets.

Addition of microbial phytase had no effect on nutrient digestibility. Supplementation of phytase to diets of pigs had a substantial positive effect on $\mathrm{P}$ digestibility. Therefore, $\mathrm{P}$ excretion can be lower and thus environmental phosphorus pollution may be reduced. 


\section{REFERENCES}

AOAC, 1990. Official Methods of Analysis, Association of Official Analytical Chemists. 15th Edition. Arlington, VA

Düngelhoef M., Rodehutscord M., 1995. Wirkung von Phytasen auf die Verdaulichkeit des Phosphors beim Schwein. Übers. Tierernähr. 23, 133-157

Fernández J.A., 1995. Calcium and phosphorus metabolism in growing pigs. II. Simultaneous radio-calcium and radio-phosphorus kinetics. Livest. Prod. Sci. 41, 234-254

Gifford S.R., Clydesdale M., 1990. Interactions among calcium, zinc and phytate with three protein sources. J. Food Sci. 55, 1720-1724

Gundel J., Regius Mőcsényi Á., Hermán A., Votisky E., Huszár Sz., Vígh L., 1998. Relationships between ecological balance and nitrogen and phosporus supply of pigs. 1st paper: Utilization of phosphorus in piglet rearing depend upon the type of phosphorus source and with and without the usage of enzymes (in Hungarian). Állattenyésztés 47, 423-434

Günther K.D., Al-Masri M.R., 1988. Untersuchungen zum Einfluss einer variierten Phosphorversorgung auf den P-Umsatz und die endogene P-Ausscheidung beim wachsenden Geflügel mit Hilfe von ${ }^{32}$ P. J. Anim. Physiol. Anim. Nutr. 59, 132-142

Hartman G.H. Jr., 1979. Removal of phytate from soy protein. J. Amer. Oil Chem. Soc. 56, 731735

Hoppe P.P., 1992. Überblick über die biologischen Wirkungen und ökologische Bedeutung der Phytase beim Schwein. 4. Forum Tiernährung der BASF AG. Ludwigshafen/Rhein, pp. 3-15

Jongbloed A.W., Everts H., 1992. Apparent digestible phosphorus in the feeding of pigs in relation to availability, requirement and environment. 2. The requirement of digestible phosphorus for piglets, growing-finishing pigs and breeding sows. Neth. J. Agr. Sci. 40, 123-136

Kemme P.A., Jongbloed A.W., Mroz Z., Beynen A.C., 1999. Digestibility of nutrients in growing-finishing pigs is affected by Aspergillus niger phytase, phytate and lactic acid levels. 2. Apparent total tract digestibility of phosphorus, calcium and magnesium and ileal degradation of phytic acid. Livest. Prod. Sci. 58, 119-127

Khan N., Cole D.J.A., 1993. The effect of dietary inclusions of phytase and yeast on apparent phosphorus digestibility in pigs. In: Proceedings of Winter Meeting of the British Society of Animal Production, Scarborough (England), p. 2

Kirchgessner M., 1994. Mitteilungen des Ausschusses für Bedarfsnormen der Gesellschaft für Ernährungsphysiologie: Die Bestimmung des verdaulichen Phosphors beim Schwein. Proc. Soc. Nutr. Physiol. 2, 113-119

NRC, 1998. Nutrient Requirements of Swine. 10th revised Edition. National Academy Press, Washington, DC

Pallauf J., Rimbach G., Pippig S., Schindler B., Most E., 1994. Effect of phytase supplementation to a phytase-rich diet based on wheat, barley and soya on the bioavailability of dietary phosphorus, calcium, magnesium, zinc and protein in piglets. Agribiol. Res. 47, 39-48

Rodehutscord M., 2001. Der gegenwärtige Stand der Phosphorbewertung für Nutztiere. Lohmann Inform. 1, 26-34

Rodehutscord M., Haverkamp R., Pfeffer E., 1998. Inevitable losses of phosphorus in pigs, estimated from balance data using diets deficient in phosphorus. Arch. Anim. Nutr. 51, 27-38

Schulz E., 1997. Phosphorus requirement and supply recommendations for pigs. Kraftfutter 9, 372384

Traylor S.L., Cromwell G.L., Lindemann M.D., Knabe D.A., 2001. Effects of level of supplemental phytase on ileal digestibility of amino acids, calcium, and phosphorus in dehulled soybean meal for growing pigs. J. Anim. Sci. 79, 2634-2642 


\section{STRESZCZENIE}

\section{Zmiany strawności pozornej składników pokarmowych i fosforu jako funkcja źródła fosfo- ru i dodatku fitazy do dawki}

Celem badań było określenie wpływu dodatku fitazy na pozorną strawność i absorpcję fosforu (P) z diety kukurydziano-sojowej, do której dodawano różną ilość nieograniczonych związków P. Doświadczenie przeprowadzono na wieprzkach-mieszańcach, o początkowej m.c. $15-18 \mathrm{~kg}$, w układzie czynnikowym $2 \times 2$ : dwa poziomy P ogólnego (A: 0,67 i L: 0,59\%) przy różnym stopniu dostępności P (A: 0,36 i L: 0,28\%) oraz dwa poziomy fitazy mikrobiologicznej (0 i $500 \mathrm{FTU} / \mathrm{kg}$ diety).

W pierwszym okresie doświadczenia świnie z grup 1/a i 1/b otrzymywały paszę o dwóch poziomach P (A i L), bez dodatku fitazy. W okresie 2, te same zwierzęta otrzymywały dawki A i L z dodatkiem enzymu (grupy 2/a i 2/b). Dodatek fitazy nie miał wpływu na strawność składników pokarmowych. Strawność substancji organicznej i ekstraktu eterowego była gorsza u świń otrzymujących dawkę L. Strawność P całkowitego wynosiła w grupie $1 / \mathrm{a}$, podobnie jak w grupie $1 / \mathrm{b}$, ok. 52\%. Dodatek fitazy spowodował wzrost strawności P całkowitego o $7 \% \mathrm{w}$ grupie $2 / \mathrm{a}$ i o $23 \% \mathrm{w}$ grupie $2 / \mathrm{b}$, a strawność $\mathrm{P}$ pochodzącego $z$ fosforanu jednowapniowego obniżyła się o 11 i $4 \%$ w grupach $2 / a$ i $2 /$ b, odpowiednio. Dodatek fitazy zwiększył pozorną strawność P z 31,6 do 43,9\% i z 35,8 do 54,5\%, odpowiednio u świń otrzymujących dawki 2/a i 2/b. Wyniki wskazują, że ilość P nieorganicznego wydalanego w kale zwiększa się, a absorpcja P poprawia się na skutek działania fitazy.

W podsumowaniu autorzy stwierdzają, że ilość dodawanego P nieorganicznego do dawek może być zmniejszona przez dodatek fitazy mikrobiologicznej, co ma duże znaczenie dla środowiska. 